\title{
Effect of dietary phosphorus supplementation on the uptake of radioactive strontium in rats
}

\author{
By G. E. HARRISON, G. R. HOWELLS AND JILL POLLARD \\ Medical Research Council Radiobiological Research Unit, \\ Harwell, Didcot, Berks
}

AND KRISTA KOSTIAL AND R. MANITAŠEVIC

Institute for Medical Research, Zagreb, Yugoslavia

(Received 10 November 1965-Accepted I February 1966)

\begin{abstract}
1. After feeding radioactive markers ${ }^{85} \mathrm{Sr}$ and ${ }^{45} \mathrm{Ca}$ for 10 days to weanling and adult rats receiving basal diets all of which contained adequate calcium and phosphorus to support normal growth, the skeletal retention of the markers was compared with that in litter-mates receiving seven different $P$ compounds as dietary supplements so that the $P$ intake was increased 2 to $3 \frac{1}{2}$ times. 2. In weanling rats a dietary supplement of $\mathrm{KH}_{2} \mathrm{PO}_{4}$ decreased the skeletal retention of ${ }^{85} \mathrm{Sr}$ by some $30 \%$ without affecting the retention of ${ }^{45} \mathrm{Ca}$. In adults on this supplement, the skelctal retention of ${ }^{85} \mathrm{Sr}$ was reduced by over $40 \%$ compared with controls on the same basal diet. 3. When the supplement contained $\mathrm{Ca}$ as well as $\mathrm{P}$ the reduction in skeletal retention of ${ }^{85} \mathrm{Sr}$ in young and adult rats was greater than when no $\mathrm{Ca}$ was present in the supplement. 4. It is concluded that thete was no experimental evidence to show that supplements of $P$ which also contained $\mathrm{Ca}$ induced any $\mathrm{Ca}$ deficiency in the rats. 5. In rats receiving $\mathrm{P}$ supplements which also contained $\mathrm{Ca}$, the ratio of the skeletal retention of ${ }^{85} \mathrm{Sr}$, experimental to controls, was 0.45 for weanling rats and 0.52 in adults, 34 weeks old. These ratios were not significantly different for any of the seven supplements used. 6. From comparisons with previous experiments, it is concluded that supplementation with $\mathbf{C a}$ plus $\mathbf{P}$ is more promising as a remedial measure for decreasing the uptake of radioactive $\mathrm{Sr}$ from the diet than supplementation with $\mathrm{Ca}$ alone.
\end{abstract}

Many attempts have been made to decrease the oral absorption of radioactive strontium both in experimental animals and in man (MacDonald, Spain, Ezmirlian \& Rounds, r955; Wasserman \& Comar, r960; Carlqvist \& Nelson, I960; Spencer, I 963 ; Bruce, I963; Harrison, I964; Volf \& Roth, I965; Volf, I965). Most of these investigations have been devoted to the study of the acute effect, i.e. they were attempts to decrease the uptake of a single dose of radioactive $\mathrm{Sr}$ given at the same time as the therapeutic agent. Information from such studies is directly relevant to cases of accidental ingestion of radioactive $\mathrm{Sr}$, but is of little assistance in formulating remedial measures which could be applied to the more general problem of a population exposed to a continuous intake of ${ }^{90} \mathrm{Sr}$ in the diet. The long-term toxicity of the therapeutic agent is of major importance in the latter instance. Agents which reduce the oral uptake of $\mathrm{Sr}$ often produce an even larger depletion in the calcium absorption (Catch \& Melchinger, 1959; Schubert, 1958), and such depletion of the natural metabolite over a lengthy period might well be considered to outweigh the advantages of the therapy.

Some of the present authors (Kostial, Lutkić, Gruden, Vojvodić \& Harrison, I963) observed in a short-term experiment on young rats that doubling the phosphorus content of the diet, by the addition of $\mathrm{KH}_{2} \mathrm{PO}_{4}$, reduced the skeletal retention of orally administered ${ }^{85} \mathrm{Sr}$ by some $40 \%$ and Spencer, Menczel \& Samachson (1964) concluded 
that the absorption of a single tracer dose of ${ }^{85} \mathrm{Sr}$ in man was decreased by dietary supplements of glycerophosphate. Results of such studies stimulated us to compare the protective effect of oral doses of several $\mathrm{P}$ compounds when incorporated in the diet of rats exposed to a continuous dietary intake of radioactive Sr. The main interest was an evaluation of the comparative protective effects of supplementation with various chemical forms of phosphate against the uptake of radioactive Sr. The most effective supplement could then be given for a longer period.

The $\mathbf{P}$ compounds chosen and the amounts of each added to the diet were not expected to have any marked effect on the normal metabolism of the rats. Usually, $\mathrm{Ca}$ as well as $\mathrm{P}$ was a component of the dietary supplement so that any decrease in $\mathrm{Ca}$ absorption caused by the phosphate additive might be expected to be largely offset by an increase in the $\mathrm{Ca}$ intake.

The initial investigation was carried out at Harwell, but larger numbers of rats on a somewhat lower basic $\mathbf{P}$ intake were later studied at Zagreb. As the purpose of both studies and the results obtained were similar, they are presented together in the present report.

\section{EXPERIMENTAL}

\section{General}

In a previous study on the effect of doubling the dietary $\mathrm{Ca}$ on the uptake of radioactive $\mathrm{Sr}$ in rats (Harrison, 1964) it was shown that for an exact evaluation of the longterm protection, the feeding of a dietary supplement to rats should be continued until radioactive equilibrium between the different body compartments, particularly between the diet and the skeleton, had been more or less attained. Thus, in young rats, the specific activity of $\mathrm{Sr}$ in bone reached about $90 \%$ of that in the diet after $\mathrm{I} 4$ weeks on the $\mathrm{Ca}$-supplemented diet, but in mature rats the specific activity was only about $13 \%$ of that in the diet after nearly ro weeks on the supplemented diet. Indeed in the latter instance, it was estimated that full body equilibrium of the radioactive $\mathrm{Sr}$ would be unlikely even if the supplemented diet had been fed to the animals for the remainder of their life. Nevertheless, it was observed that the ratio of the skeletal retention of radioactive $\mathrm{Sr}$ in rats given a $\mathrm{Ca}$ supplement to that in animals which received no such supplement remained constant to within $10 \%$ from ro to 100 days. Accordingly, the ratio of the skeletal retentions after the rats had been on the various phosphate supplements for Io days was used in the study now presented to assess the most effective form of supplementation.

\section{Harwell experiments}

For the young rats, the basal diet was that shown in Table $\mathrm{I}$ of the earlier paper (Harrison, 1964). The $\mathrm{Ca}$ and $\mathrm{P}$ contents per $100 \mathrm{~g}$ diet were 0.56 and $0.66 \mathrm{~g}$ respectively. The diet was mixed to a paste-like consistency with distilled water and the daily ration per rat was $13 \mathrm{~g}$. Twenty-four female inbred albino rats were put on this basal diet at weaning. When 5 weeks old they were divided into seven groups and known amounts of approximately carrier-free ${ }^{85} \mathrm{Sr}$ and ${ }^{45} \mathrm{Ca}$ in distilled water were added to the basal diet so that the daily intake of each tracer was about $0 \cdot 1 \mu \mathrm{c}$. The control 
group (six rats) received the basal diet, the other groups, each of three rats, received the various supplements shown in Table $\mathrm{I}$ mixed in the basal diet so that the $P$ intake of the rats receiving supplementary $P$ was twice that of the control animals. One group was given $\mathrm{KCl}$ as a supplement to assess the effect of potassium on the excretion and retention of the radioactive markers in the absence of any phosphate additive. The potassium supplements in the chloride and dihydrogen phosphate additives were equal.

To investigate the effect of age, nine mature rats ( 18 weeks old) were used. These had been on the stock laboratory diet $(\mathrm{I} \cdot \mathrm{I} \mathrm{g} \mathrm{Ca}, 0 \cdot 66 \mathrm{~g} \mathrm{P}$ per roo g diet) since weaning and to avoid the complication introduced by a change in the basal diet, these animals all received crushed cubes of the stock diet moistened with distilled water to a paste. ${ }^{85} \mathrm{Sr}$ and ${ }^{45} \mathrm{Ca}$ in distilled water were added to the food mixture so that the daily ration of $15 \mathrm{~g}$ contained about $0.1 \mu \mathrm{c}$ of each tracer. The grouping and dietary supplementation were as shown in Table $\mathrm{I}$. In all instances distilled water was given ad lib.

Each rat was kept in a metabolism cage (Howells, Wright \& Harrison, 1964) and separate collections of urine and faeces were made from each animal.. Ten days later the rats were killed and the skeletons dissected free from soft tissue.

The urine produced in 10 days from each rat was acidified, and ${ }^{85} \mathrm{Sr}$ was determined in a representative sample on a well-type gamma scintillation counter. Bulked faeces and the separate skeletons were dried, ashed and dissolved in hydrochloric acid for the determination of ${ }^{85} \mathrm{Sr} .{ }^{45} \mathrm{Ca}$ in each of the acid solutions was measured on a scintillation beta counter by a method developed by Carr \& Parsons (1962). Stable Ca was estimated with a flame spectrophotometer and $\mathrm{P}$ in the ashed diet and in the supplement by the colorimetric method of Allen (1940).

\section{Zagreb experiments}

The skeletal retention of radioactive $\mathrm{Sr}$ and $\mathrm{Ca}$ when different phosphate supplements were added to the basal diet for Io days was again compared with their retention in rats receiving no phosphate supplementation. The $P$ supplements are shown in Table I.

The basal diet was the stock cube laboratory diet ( $\mathrm{Ca} \mathrm{r} \cdot 0$ and $\mathrm{P} 0.5 \mathrm{~g}$ per Ioo g diet). This was powdered so that the various supplements could be added. The amount of each supplement was such that the $\mathbf{P}$ content of the supplemented diet was about three times that of the basal diet (controls). The food preparation and the feeding routine were similar to those used at Harwell except that the radioactive markers were added to the drinking water. ${ }^{85} \mathrm{Sr}$ was used as the radioactive marker for $\mathrm{Sr}$ but the marker for $\mathrm{Ca}$ was the $\gamma$-emitting isotope, ${ }^{47} \mathrm{Ca}$, with a half-life of $4 \cdot 7$ days. The average daily intake of each of these markers was about $0.1 \mu \mathrm{c}$ per rat. No collections of urine and faeces were made in these experiments.

After the animals had been killed, the skeletons were dissected free of soft tissue and radioactive assays on the acid digest of the ashed bone for ${ }^{47} \mathrm{Ca}$ and ${ }^{85} \mathrm{Sr}$ were made with a well-type scintillation counter and a single channel analyser (Kostial et al. I963). The $\mathrm{Ca}$ contents of the diet and of the supplements were estimated by a standard 
oxalate-permanganate procedure (Kolthoff \& Sandell, 1952) and $\mathrm{P}$ was determined by colorimetric estimation of the phosphomolybdate (Association of Official Agricultural Chemists, 1955).

\section{RESULTS}

Table I gives the $\mathrm{Ca}$ and $\mathrm{P}$ contents of the basal and supplemented diets in the Harwell and Zagreb experiments. At Harwell, the phosphate supplement was by design always equal to the phosphate content of the basal diet and when supplementary $\mathrm{Ca}$ was added, the ratio of $\mathrm{Ca}$ in the supplemented diet to that in the basal diet was about 2.6 for the young rats and $\mathrm{r} \cdot 8$ for the mature rats. In the Zagreb experiments, the ratios of $\mathrm{P}$ and $\mathrm{Ca}$ in the supplemented diet to the $\mathrm{P}$ and $\mathrm{Ca}$ in the control diet were about 3 and $2 \cdot 3$ respectively for both age groups.

Table I. Age groups of rats and calcium and phosphorus content of the basal (control) and supplemented diets

\begin{tabular}{|c|c|c|c|c|c|c|c|}
\hline \multirow[b]{3}{*}{$\begin{array}{l}\text { Age at death } \\
\text { (weeks) }\end{array}$} & \multicolumn{3}{|c|}{ Harwell experiments } & \multicolumn{4}{|c|}{ Zagreb experiments } \\
\hline & & $\begin{array}{c}\text { Dietary } \\
\mathrm{Ca}\end{array}$ & $\begin{array}{l}\text { Dietary } \\
\text { P }\end{array}$ & & & $\begin{array}{c}\text { Dietary } \\
\mathrm{Ca}\end{array}$ & $\begin{array}{c}\text { Dietary } \\
\mathrm{P}\end{array}$ \\
\hline & Diet & $\overbrace{(\mathrm{g} / \mathrm{10}}$ & & $\begin{array}{l}\text { Age at death } \\
\text { (weeks) }\end{array}$ & Diet & $(\mathrm{g} / \mathrm{xo}$ & g diet) \\
\hline 7 & Basal & 0.55 & 0.66 & 8 & Basal & $\mathrm{I} \cdot 02$ & 0.53 \\
\hline 7 & Basal + I & 0.55 & 0.66 & 8 & Basal +3 & $2 \cdot 22$ & $I \cdot 46$ \\
\hline 7 & Basal + 2 & 0.55 & I'33 & 8 & Basal +4 & $2 \cdot 21$ & $I \cdot 45$ \\
\hline 7 & Basal +3 & $I \cdot 41$ & $I \cdot 33$ & 8 & Basal +5 & $2 \cdot 40$ & $r \cdot 60$ \\
\hline 7 & Basal + 4 & $x \cdot 43$ & $1 \cdot 34$ & 8 & Basal +7 & $2 \cdot 24$ & $\mathrm{I} \cdot 48$ \\
\hline 7 & Basal + 5 & $1 \cdot 43$ & $I \cdot 34$ & 34 & Basal & $1 \cdot 02$ & 0.53 \\
\hline 7 & Basal +6 & $1 \cdot 43$ & $I \cdot 34$ & 34 & Basal +3 & $2 \cdot 22$ & $I \cdot 46$ \\
\hline 20 & Basal & $I \cdot 10$ & 0.66 & 34 & Basal +4 & $2 \cdot 21$ & $x-45$ \\
\hline 20 & Basal + 2 & I. IO & $\mathrm{I} \cdot 32$ & 34 & Basal +5 & $2 \cdot 40$ & $I \cdot 60$ \\
\hline 20 & Basal +3 & $\mathrm{I} \cdot 95$ & $1 \cdot 32$ & 34 & Basal +7 & $2 \cdot 24$ & $1 \cdot 48$ \\
\hline
\end{tabular}

Supplement: 1, potassium chloride; 2 , potassium dihydrogen phosphate; 3 , calcium hydrogen phosphate; 4, calcium glycerophosphate; 5 , calcium phytate; 6 , calcium pyrophosphate; 7 , sodium hexametaphosphate + calcium chloride.

Table 2. Harwell experiment. Mean excretion and body retention of ${ }^{85} \mathrm{Sr}$ and ${ }^{45} \mathrm{Ca}$ expressed as percentages of the total oral dose in young and mature rats receiving different dietary supplements

\begin{tabular}{|c|c|c|c|c|c|c|c|c|}
\hline \multirow[b]{2}{*}{ Supplement* } & \multirow{2}{*}{$\begin{array}{l}\text { Age at } \\
\text { death } \\
\text { (weeks) }\end{array}$} & \multirow{2}{*}{$\begin{array}{l}\text { No. } \\
\text { of } \\
\text { rats }\end{array}$} & \multicolumn{2}{|c|}{$\begin{array}{c}\text { Mean } \\
\text { urinary output }\end{array}$} & \multicolumn{2}{|c|}{$\begin{array}{c}\text { Mean } \\
\text { faecal output }\end{array}$} & \multicolumn{2}{|c|}{$\begin{array}{c}\text { Body retention, } \\
\text { dose - output }\end{array}$} \\
\hline & & & ${ }^{85} \mathrm{Sr}$ & ${ }^{45} \mathrm{Ca}$ & ${ }^{85} \mathrm{Sr}$ & ${ }^{45} \mathrm{Ca}$ & ${ }^{85} \mathrm{Sr}$ & ${ }^{45} \mathrm{Ca}$ \\
\hline None (control) & 7 & 6 & $2 \cdot 6$ & 0.5 & 75 & 46 & 22 & 53 \\
\hline$I$ & 7 & 3 & $3 \cdot 2$ & 0.8 & 77 & 46 & 20 & 53 \\
\hline 2 & 7 & 3 & $1 \cdot 0$ & 0.2 & 84 & $5 \mathrm{I}$ & I 5 & 49 \\
\hline 3 & 7 & 3 & 0.7 & 0.25 & 89 & 76 & IO & 24 \\
\hline 4 & 7 & 3 & 0.95 & 0.3 & 89 & 75 & IO & 25 \\
\hline 5 & 7 & 3 & $1 \cdot 2$ & 0.4 & 87 & 70 & 12 & 30 \\
\hline 6 & 7 & 3 & $1 \cdot 0$ & 0.3 & 87 & 70 & 12 & 30 \\
\hline None (control) & 20 & 3 & 2.9 & $\mathbf{x} 7$ & $9 \circ$ & 82 & $7 \cdot \mathbf{I}$ & $16 \cdot 3$ \\
\hline 2 & 20 & 3 & 0.7 & 0.3 & 92 & 82 & $7 \cdot 3$ & $x 7 \cdot 7$ \\
\hline 3 & 20 & 3 & $\mathrm{I} \cdot 4$ & 0.7 & 93 & $8_{3}$ & $5 \cdot 6$ & $x 6 \cdot 3$ \\
\hline
\end{tabular}


Table 2 gives the total urinary and faecal excretion of ${ }^{85} \mathrm{Sr}$ and ${ }^{45} \mathrm{Ca}$ expressed as the percentage of the total oral dose for rats receiving the different supplements. Except for the slight increase in the urinary output of both markers with the $\mathrm{KCl}$ supplement, there was a marked decrease in the urinary excretion of both markers with all the dietary supplements. A similar result was obtained by Kostial, Vojvodić, Gruden \& Lutkic (I 964 ) for a $\mathrm{KH}_{2} \mathrm{PO}_{4}$ supplement. In the younger rats, the excretion of ${ }^{85} \mathrm{Sr}$ and ${ }^{45} \mathrm{Ca}$ in faeces increased appreciably with all supplements except $\mathrm{KCl}$.

Table 3. Harwell experiment. Mean skeletal retentions of ${ }^{85} \mathrm{Sr}$ and ${ }^{45} \mathrm{Ca}$ expressed as percentages of the total oral dose in young and mature rats receiving different dietary supplements

\begin{tabular}{|c|c|c|c|c|c|c|}
\hline \multirow[b]{2}{*}{ Supplement* } & \multirow{2}{*}{$\begin{array}{c}\text { Age at } \\
\text { death } \\
\text { (weeks) }\end{array}$} & \multicolumn{2}{|c|}{$\begin{array}{c}\text { Mean } \\
\text { skeletal retention }\end{array}$} & \multirow{2}{*}{$\begin{array}{l}\text { Ratio of } \\
\text { mean } \\
\text { skeletal } \\
\text { retention, } \\
{ }^{85} \mathrm{Sr}:{ }^{45} \mathrm{Ca}\end{array}$} & \multicolumn{2}{|c|}{$\begin{array}{l}\text { Ratio of mean } \\
\text { skeletal retention, } \\
\text { experimental: control }\end{array}$} \\
\hline & & ${ }^{85} \mathrm{Sr}$ & ${ }^{45} \mathrm{Ca}$ & & ${ }^{85} \mathrm{Sr}$ & ${ }^{45} \mathrm{Ca}$ \\
\hline None (control) & 7 & $16 \cdot I$ & 49.4 & 0.33 & I & I \\
\hline I & 7 & $16 \cdot 4$ & $5 I \cdot 2$ & 0.32 & $1 \cdot 02$ & 1.07 \\
\hline 2 & 7 & II 4 & $48 \cdot 2$ & 0.24 & 0.71 & $I \cdot O I$ \\
\hline 3 & 7 & $5 \cdot 4$ & $2 \mathrm{I} \cdot 2$ & 0.26 & 0.34 & 0.44 \\
\hline 4 & 7 & $5 \cdot 9$ & $2 x \cdot 8$ & 0.28 & 0.37 & 0.46 \\
\hline 5 & 7 & $6 \cdot 9$ & 24.7 & 0.28 & 0.43 & $0 \cdot 49$ \\
\hline 6 & 7 & $5 \cdot 9$ & $24 \cdot 6$ & 0.24 & 0.37 & 0.49 \\
\hline None (control) & 20 & $2 \cdot 7$ & $7 \cdot 5$ & 0.36 & I & $\mathbf{r}$ \\
\hline 2 & 20 & $I \cdot 5$ & $6 \cdot 2$ & 0.24 & 0.54 & 0.83 \\
\hline 3 & 20 & $I \cdot 5$ & 4.7 & 0.32 & 0.54 & 0.59 \\
\hline
\end{tabular}

* The number of rats receiving each supplement is given in Table 2 and the supplements are listed in the footnote to Table $\mathrm{I}$.

Table 4. Zagreb experiment. Mean skeletal retentions of ${ }^{85} \mathrm{Sr}$ and ${ }^{47} \mathrm{Ca}$ with their standard errors expressed as percentages of the total oral dose in young and adult rats receiving different dietary supplements

\begin{tabular}{|c|c|c|c|c|c|c|c|}
\hline \multirow[b]{2}{*}{ Supplement* } & \multirow{2}{*}{$\begin{array}{l}\text { Age at } \\
\text { death } \\
\text { (weeks) }\end{array}$} & \multirow{2}{*}{$\begin{array}{l}\text { No. } \\
\text { of } \\
\text { rats }\end{array}$} & \multicolumn{2}{|c|}{$\begin{array}{c}\text { Mean } \\
\text { skeletal retention }\end{array}$} & \multirow{2}{*}{$\begin{array}{c}\text { Ratio } \\
\text { of mean } \\
\text { skeletal } \\
\text { retention, } \\
{ }^{\mathbf{8} 5} \mathrm{Sr}:{ }^{\mathbf{4}} \mathrm{Ca}\end{array}$} & \multicolumn{2}{|c|}{$\begin{array}{c}\text { Ratio of mean } \\
\text { skeletal retention, } \\
\text { experimental:control }\end{array}$} \\
\hline & & & ${ }^{85} \mathrm{Sr}$ & ${ }^{47} \mathrm{Ca}$ & & ${ }^{85} \mathrm{Sr}$ & ${ }^{47} \mathrm{Ca}$ \\
\hline None (control) & 8 & 8 & $9.8 \pm 0.33$ & $25 \cdot 2 \pm 0.55$ & $0.39 \pm 0.015$ & I & I \\
\hline 3 & 8 & 8 & $4.3 \pm 0.17$ & $14.0 \pm 0.41$ & $0.31 \pm 0.015$ & $0.44 \pm 0.022$ & $0.56 \pm 0.020$ \\
\hline 4 & 8 & 8 & $4.7 \pm 0.17$ & $14.2 \pm 0.38$ & $0.33 \pm 0.015$ & $0.48 \pm 0.024$ & $0.56 \pm 0.019$ \\
\hline 5 & 8 & 8 & $4.2 \pm 0.12$ & $13.4 \pm 0.32$ & $0.31 \pm 0.012$ & $0.43 \pm 0.019$ & $0.53 \pm 0.017$ \\
\hline 7 & 8 & 7 & $4.2 \pm 0.15$ & I $5.1 \pm 0.56$ & $0.28 \pm 0.014$ & $0.43 \pm 0.02 I$ & $0.60 \pm 0.026$ \\
\hline None (control) & 34 & 8 & $2 \cdot 5 \pm 0.1 \mathrm{I}$ & $8.0 \pm 0.26$ & $0.31 \pm 0.017$ & I & I \\
\hline 3 & 34 & 8 & $1.4 \pm 0.07$ & $4.2 \pm 0.25$ & $0.33 \pm 0.026$ & $0.56 \pm 0.039$ & $0.53 \pm 0.036$ \\
\hline 4 & 34 & 8 & $I \cdot 2 \pm 0.1 I$ & $4.2 \pm 0.29$ & $0.29 \pm 0.033$ & $0.48 \pm 0.051$ & $0.53 \pm 0.040$ \\
\hline $\begin{array}{l}+ \\
5\end{array}$ & 34 & 8 & $1 \cdot 2 \pm 0.14$ & $3.9 \pm 0.35$ & $0.31 \pm 0.046$ & $0.48 \pm 0.061$ & $0.49 \pm 0.036$ \\
\hline $\begin{array}{l}5 \\
7\end{array}$ & $\begin{array}{l}34 \\
34\end{array}$ & 8 & $1 \cdot 2 \pm 0.09$ & $3.9 \pm 0.25$ & $0.31 \pm 0.029$ & $0.48 \pm 0.041$ & $0.49 \pm 0.036$ \\
\hline
\end{tabular}

The final column of Table 2 gives the body retention derived as dose minus excretion. A maximal decrease in the body retention of ${ }^{85} \mathrm{Sr}$ was observed in young rats receiving the phosphate supplements containing $\mathrm{Ca}$, and particularly with calcium hydrogen phosphate and calcium glycerophosphate. 
The body retentions of ${ }^{45} \mathrm{Ca}$ for all supplements containing $\mathrm{Ca}$ as well as $\mathrm{P}$ was about half that for the controls. For mature rats, the derived values for body retention are more difficult to interpret because of the higher excretion of the radioactive markers.

The mean skeletal retentions of ${ }^{85} \mathrm{Sr}$ and ${ }^{45} \mathrm{Ca}$ expressed as a percentage of the total oral dose for rats receiving the different supplements are shown in Table 3 together with the ratio of the mean skeletal retention of ${ }^{85} \mathrm{Sr}$ to ${ }^{45} \mathrm{Ca}$ and that of ${ }^{85} \mathrm{Sr}$ experimental to control. Differences in the experimental results for rats on the $\mathrm{KCl}$ supplement and the controls were regarded as within the experimental error. For both young and mature rats on the $\mathrm{KH}_{2} \mathrm{PO}_{4}$ supplement there was an appreciable decrease in the skeletal retention of ${ }^{85} \mathrm{Sr}$ without any corresponding large decrease in the skeletal retention of ${ }^{45} \mathrm{Ca}$ so that the ratio of the skeletal retentions of ${ }^{85} \mathrm{Sr}$ to ${ }^{45} \mathrm{Ca}$ decreased. In the remainder, i.e. rats receiving both $\mathrm{Ca}$ and $\mathrm{P}$ in the supplement, the ratio of the skeletal retention of ${ }^{85} \mathrm{Sr}$ experimental to control was about 0.4 in young rats and rather greater in mature rats.

Table 4 gives the Zagreb results for the mean skeletal retention of ${ }^{85} \mathrm{Sr}$ and ${ }^{47} \mathrm{Ca}$ for rats on the control and supplemented diets. As might be excepted, the higher Ca content of the basal diet for the young rats compared with that of the corresponding diet used at Harwell had a marked effect on the skeletal retentions of both markers, but the ratio of the skeletal retentions experimental to control obtained by the two teams are in satisfactory agreement (Tables 3 and 4 ) despite differences in the degree of supplementation with phosphate in the two experiments.

\section{DISCUSSION}

The present investigation was designed to study the effect of different forms of dietary $\mathrm{P}$ supplementation on the skeletal retention of radioactive $\mathrm{Sr}$ in rats on a basal diet in which the $\mathrm{P}$ was adequate for normal growth. Very different results have been obtained for rats on an inadequate $P$ intake (Ray, Stedman \& Wolff, 1956; Palmer, Thompson \& Kornberg, 1958; van Putten, 1962) so that extrapolation of the present results to a wide range of $\mathrm{P}$ intake, both physiological and non-physiological, would be very misleading. Results of the present experiments give useful preliminary information on remedial measures which might be taken to reduce the dietary uptake of ${ }^{90} \mathrm{Sr}$ for a human population presumed to be on an adequate $P$ intake.

Since the $\mathrm{KCl}$ supplement had practically no effect on the skeletal retention of ${ }^{85} \mathrm{Sr}$ and ${ }^{45} \mathrm{Ca}$, we may conclude that the decreased skeletal retentions observed with $\mathrm{KH}_{2} \mathrm{PO}_{4}$ were due to the phosphate and not to the potassium ion. Table 3 shows that, though the skeletal retention of ${ }^{85} \mathrm{Sr}$ in rats given this supplement was appreciably less than that in the controls receiving no such supplement, the skeletal retention of ${ }^{45} \mathrm{Ca}$ was unchanged in young rats and decreased to a much smaller degree than that for ${ }^{85} \mathrm{Sr}$ in the adults. It may be concluded that dietary supplementation with $\mathrm{KH}_{2} \mathrm{PO}_{4}$ reduces the skeletal retention of ${ }^{85} \mathrm{Sr}$ without materially affecting the uptake of $\mathrm{Ca}$. 
It has been shown for young rats on an adequate $\mathrm{Ca}$ intake that if the dietary $\mathrm{Ca}$ is doubled, the skeletal retention of the ${ }^{45} \mathrm{Ca}$ marker in the diet is almost halved (Harrison, 1964). It is of interest, therefore, to compare the mean dietary ratio of $\mathrm{Ca}$, in young and mature rats receiving the various calcium phosphate supplements, with the inverse ratio of the mean skeletal retention of the ${ }^{45} \mathrm{Ca}$ marker. This comparison is shown in Table 5. It will be seen that there tended to be an inverse relationship between the skeletal retention of ${ }^{45} \mathrm{Ca}$ and the $\mathrm{Ca}$ content of the diet, especially in young rats. Such a condition would imply that the blood levels of the ${ }^{45} \mathrm{Ca}$ marker were also approximately in inverse ratio to the Ca content of the diet. One important

Table 5. Ratio of calcium in control diet to that in supplemented diets (a) compared with the ratio of skeletal retention of radioactive $C a$ in rats on experimental diets to those on control diet $(b)$

\begin{tabular}{|c|c|c|c|c|c|}
\hline \multirow{2}{*}{$\begin{array}{l}\text { Supple- } \\
\text { ment* }\end{array}$} & \multirow{2}{*}{$\begin{array}{c}\text { Age } \\
\text { group }\end{array}$} & \multicolumn{2}{|c|}{ Harwell experiment } & \multicolumn{2}{|c|}{ Zagreb experiment } \\
\hline & & (a) & (b) & (a) & (b) \\
\hline 2) & & $\mathbf{I}$ & I.OI & - & - \\
\hline 3 & & 0.39 & 0.44 & 0.46 & 0.56 \\
\hline 4 & Young & 0.39 & 0.46 & 0.46 & 0.56 \\
\hline 5 & & 0.39 & 0.49 & 0.43 & 0.53 \\
\hline 6 & & 0.39 & 0.49 & - & - \\
\hline 7) & & - & 二 & 0.46 & 0.60 \\
\hline 2$)$ & & I & 0.83 & - & - \\
\hline 3 & & $0.5 \mathrm{I}$ & 0.59 & 0.46 & 0.53 \\
\hline 4 & & & - & $0 \cdot 46$ & 0.53 \\
\hline 5 & Aduit & - & - & 0.43 & 0.49 \\
\hline 6 & & - & - & - & - \\
\hline 7) & & - & - & 0.46 & 0.49 \\
\hline
\end{tabular}

* The number of rats receiving each supplement is given in Tables 2 and 4. The supplements are listed in the footnote to Table $I$.

difference should be noted, however: in rats on Ca supplements not containing $P$, the urinary excretion of ${ }^{45} \mathrm{Ca}$ was greater than in controls receiving no $\mathrm{Ca}$ supplementation (Harrison, 1964) whereas from Table 2 it is seen that when $\mathrm{P}$, or Ca plus $\mathrm{P}$, in the diet was increased, the urinary excretion of ${ }^{45} \mathrm{Ca}$ fell. It would seem, however, that there is no experimental evidence against the conclusion that when the $\mathrm{P}$, or $\mathrm{Ca}$ plus $\mathrm{P}$, content of the basal diet is increased two- or three-fold, the skeletal uptake of radioactive $\mathrm{Sr}$ from the diet is reduced without correspondingly affecting the skeletal turnover of $\mathrm{Ca}$. This is, of course, a primary condition for the therapeutic use of any supplements if possible toxic effects are to be avoided.

Results given in Table 3 suggest that when both $\mathrm{Ca}$ and $\mathrm{P}$ are present in the supplement there is a greater depression in the skeletal deposition of radioactive $\mathrm{Sr}$ than when the $\mathrm{P}$ supplement does not contain $\mathrm{Ca}$. The Harwell results suggest that calcium hydrogen phosphate and calcium glycerophosphate are the most effective in both age groups. However, the number of rats in each experimental group was only three, whereas in the Zagreb experiments, in which there were eight rats in each experimental group, all four supplements containing $\mathrm{Ca}$ and $\mathrm{P}$ were found to be about equally effective. We conclude that the skeletal retention of radioactive $\mathrm{Sr}$ was almost inde- 
pendent of the chemical form of the different Ca plus $P$ supplements used and that such supplementation was rather more effective in young than in adult rats, aged 33-34 weeks.

The ratio of the mean skeletal retention of ${ }^{85} \mathrm{Sr}$ to radioactive $\mathrm{Ca}$ as expressed in Tables 3 and 4 , is a measure of the overall discrimination diet to bone (Comar, Wasserman \& Nold, 1956). The ratio decreased significantly $(P<0.001)$ in the Zagreb experiments and possibly also in the Harwell series, when the supplement contained $P$. This is contrary to the result obtained when a Ca supplement which did not contain $P$ was given to rats (Harrison, I964).

It is of some interest to note that, in man on a mixed diet of brown bread labelled with ${ }^{90} \mathrm{Sr}$ and milk labelled with ${ }^{85} \mathrm{Sr}$, the relative availabilities of the two forms of radioactive Sr were equal (Carr, Harrison, Loutit \& Sutton, 1965) despite the fact that the bread was relatively rich in phytate which is known to suppress the gastrointestinal absorption of $\mathrm{Ca}$ (Mellanby, 1925; McCance \& Widdowson, 1942-3). The conclusion drawn from this experiment was that chemical mixing of the constituents of the bread and milk in the process of digestion was quite efficient, so that the absorbed fraction originated from a homogenate. It would seem probable that such chemical mixing of the various supplements with the diet in the process of digestion may well account for the similarity in the results obtained with the various $\mathrm{Ca}$ and $\mathrm{P}$ compounds used in the present experiments.

It is important to mention that full body equilibrium on the various supplemented diets as assessed by equality between the specific activity of $\mathrm{Ca}$ and $\mathrm{Sr}$ in the diet and the bone was not achieved even in the young animals. There is every indication from long-term supplementation of the diet with $\mathrm{Ca}$ (Harrison, 1964) that the ratio of the skeletal retention of radioactive $\mathrm{Sr}$ in animals on the supplemented diets, relative to rats on the basal diets, would have continued to decrease had the experimental feeding periods been prolonged. Thus, during prolonged feeding, the ratios given in the final columns of Tables 3 and 4 could well decrease by up to $10 \%$ or more; the index of protection as measured by the ratios shown in the final column of these tables is probably therefore an underestimate.

From these short-term experiments it is not certain that the various supplements were without any toxic effects. Certainly the increase in body-weight of the control and experimental groups showed no significant difference and no abnormality was observed histologically when the rats were killed. It would be necessary, however, to feed the various phosphate supplements to rats for a much longer period before such conclusions could be made.

\section{REFERENCES}

Allen, R. J. L. (1940). Biochem. F. 34, 858 .

Association of Official Agricultural Chemists (1955). Official Methods of Analysis, 8th ed., p. 35I. Washington DC: Association of Official Agricultural Chemists.

Bruce, R. S. (1963). Nature, Lond. 199, 1107.

Carlquist, B. \& Nelson, A. (1 960). Acta radiol. 54, 305.

Carr, T. E. F., Harrison, G. E., Loutit, J. F. \& Sutton, A. (1965). Proc. Nutr. Soc. 24, 120.

Carr, T. E. F. \& Parsons, B. (1962). Int. F. appl. Radiat. Isotopes 13, 57.

Catsch, A. \& Melchinger, H. (r959). Strahlentherapie, rog, 56r. 
Comar, C. L., Wasserman, R. H. \& Nold, M. M. (1956). Proc. Soc. exp. Biol. Med. 92, 859.

Harrison, G. E. (1964). Int. F. Radiat. Biol. 8, 177.

Howells, G., Wright, C. F. \& Harrison, G. E. (1964). F. Anim. Techns Ass. 14, 137.

Kolthoff, I. M. \& Sandell, E. B. (1952). Textbook of Quantitative Inorganic Analysis, 3rd ed. New York: Macmillan.

Kostial, K., Lutkić, Gruden, N., Vojvodić, S. \& Harrison, G. E. (1963). Int. F. Radiat. Biol. 6, 431.

Kostial, K., Vojvodić, S., Gruden, N. \& Lutkić, A. (1964). In Proceedings of the First European Bone and Tooth Symposium (r963), p. I I . [H. J. J. Blackwood, editor.] Oxford: Pergamon Press.

McCance, R. A. \& Widdowson, E. M. (1942-3). F. Physiol., Lond. ror, 304.

MacDonald, N. S., Spain, P. C., Ezmirlian, F. \& Rounds, D. E. (1955). F. Nutr. 57, 555.

Mellanby, E. (1925). Spec. Rep. Ser. med. Res. Coun., no. 3.

Palmer, R. F., Thompson, R. C. \& Kornberg, H. A. (1958). Science, N. Y. 128, 1505.

Ray, R. D., Stedman, D. E. \& Wolff, N. K. (1956). F. Bone $\mathfrak{f t}_{t}$ Surg. 384, 637.

Schubert, J. (1958). Atompraxis 4, 393.

Spencer, H. (1963). In Diagnosis and Treatment of Radioactive Poisoning, 1962, p. 145. Vienna: International Atomic Energy Agency.

Spencer, H., Menczel, J. \& Samachson, J. (1964). Proc. Soc. exp. Biol. Med. II7, 59.

van Putten, L. H. (1962). Int. F. Radiat. Biol. 5, $47 \mathrm{I}$.

Volf, V. (1965). Experientia 21, $57 \mathrm{I}$.

Volf, V. \& Roth, R. (1965). Acta radiol. 3, 2 I6.

Wasserman, R. H. \& Comar, C. L. (1960). Proc. Soc. exp. Biol. Med. 103, 124. 